\title{
Assessing the Effectiveness of the Non-Structural Measures for River Cleaning
}

\author{
Nor Azilah Husin ${ }^{1}$, Ahmad Fuad Noor $^{2}$, Mazni Saad ${ }^{3}$, Eka Mariyanti ${ }^{4}$ \\ 1 Faculty of Business and Accountancy, Universiti Selangor, 40000, Shah Alam, Selangor, Malaysia. \\ 2 Menteri Besar Incorporated Selangor, 40000 Shah Alam Selangor, Malaysia, \\ 3 Tourism Department, Kulliyyah of Languages and Management, International Islamic University Islam Malaysia, Edu Hub Pagoh, \\ KM1 Jalan Panchor, Muar 84600 Johor, Malaysia, \\ ${ }_{4}^{4}$ Faculty of Economics and Business, Universitas Dharma Andalas, Padang, West Sumatra-Indonesia \\ nor_azilah@unisel.edu.my, fuad@mbiselangor.com, maznisaad@iium.edu.my, ekamariyanti@yahoo.com
} Tel: +60199877271

\begin{abstract}
Klang River is heavily polluted. The state government tries to reduce this issue. The study's objective is to identify river cleaning's effectiveness by the non-structural measures of cross-sectoral collaboration and public outreach programs. A total of 82 usable data from Lembaga Urus Air Selangor (LUAS), Department of Irrigation and Drainage (DID), Klang Local Council (MPK), Shah Alam Local Council (MBSA) and the river community have answered an adapted questionnaire. We employ SmartPLS software for the analysis. The results show that Cross-sectoral Collaboration (CSC) and Public Outreach Program (POP) have significant effects on Effective River Cleaning (ERC).
\end{abstract}

Keywords: effective river cleaning; river rejuvenation; cross-sectoral collaboration; public outreach program

eISSN: 2398-4287@ 2021. The Authors. Published for AMER ABRA cE-Bs by e-International Publishing House, Ltd., UK. This is an open access article under the CC BYNC-ND license (http://creativecommons.org/licenses/by-nc-nd/4.0/). Peer-review under responsibility of AMER (Association of Malaysian Environment-Behaviour Researchers), ABRA (Association of Behavioural Researchers on Asians/Africans/Arabians) and cE-Bs (Centre for Environment-Behaviour Studies), Faculty of Architecture, Planning \& Surveying, Universiti Teknologi MARA, Malaysia.

DOI: https://doi.org/10.21834/ebpj.v6i16.2688

\subsection{Introduction}

The stakeholder structures are particularly perplexing regarding river management and reclamation projects (Wu, Ju, Wang, Gu \& Jiang, 2020). There are many issues and challenges in the restoration and management of transboundary rivers (Li, Zhang, Jiang \& Huang, 2020). Klang River reclamation project is no exception. With a catchment river basin area covering $1,280 \mathrm{~km} 2$, the Klang River winds through the most densely populated and industrialised regions of the Klang Valley. With nearly a seventh of the general populace and the amplest scope of human exercises, the Klang Valley' actual climate has gone through many human-made changes: from tin-mining in the last century to broad urbanisation and industrialisation today (Muhammad, Nur, Ismail \& Mohammadreza, 2017). The contaminations from industrial facilities and urbanisations have been paddling into the stream. The Malaysian government and the state of Selangor understood that the Klang River was not an excellent indication of different urban communities along the river any more. Instead, they were the scars of the urban communities' turn of events and an unloading ground that disengaged from individuals' everyday lives. A large amount of waste from the Klang River is mainly due to indiscriminate litter disposal, mostly plastic materials such as plastic bags, mineral water bottles, food containers, etc. However, the law's key issues are the severity of the penalties and

eISSN: 2398-4287C 2021. The Authors. Published for AMER ABRA cE-Bs by e-International Publishing House, Ltd., UK. This is an open access article under the CC BYNC-ND license (http://creativecommons.org/licenses/by-nc-nd/4.0/). Peer-review under responsibility of AMER (Association of Malaysian Environment-Behaviour Researchers), ABRA (Association of Behavioural Researchers on Asians/Africans/Arabians) and cE-Bs (Centre for Environment-Behaviour Studies), Faculty of Architecture, Planning \& Surveying, Universiti Teknologi MARA, Malaysia.

DOI: https://doi.org/10.21834/ebpj.v6i16.2688 
compliance and monitoring effectiveness. The fact that the factory in question was fined RM60,000 for the same offence shows that a fine alone is not enough to ensure enforcement and prevent emissions. The state should focus on non-structural actions by reducing and containing waste previously or moving through the climate while currently focusing on removing floating debris from the Klang River through structural measures, a more sustainable non-structural measure does not include actual development. Still, it uses information, practice, or consent to lessen debacle dangers and effects, specifically through approaches and laws, public mindfulness raising, training, and education. It aims to facilitate the collaboration of various areas to expand the responsibility and awareness of different stakeholders' specific expectations. In contrast, a public outreach program seeks to educate, raise awareness, and change the public's mindset and behaviour, moving toward a more responsible society responsible for managing waste, rather than a lackadaisical attitude of indiscriminate disposal of wastes at rivers and public areas. These non-structural cross-sectoral collaborations and public outreach programs are among the first steps that need to be accomplished. This study aims to determine how effective non-underlying measures are at lessening litter into the river. Subsequently, it is critical of this exploration in recognising, understanding and assessing the effectiveness of these non-structural measures for the Klang River cleaning project.

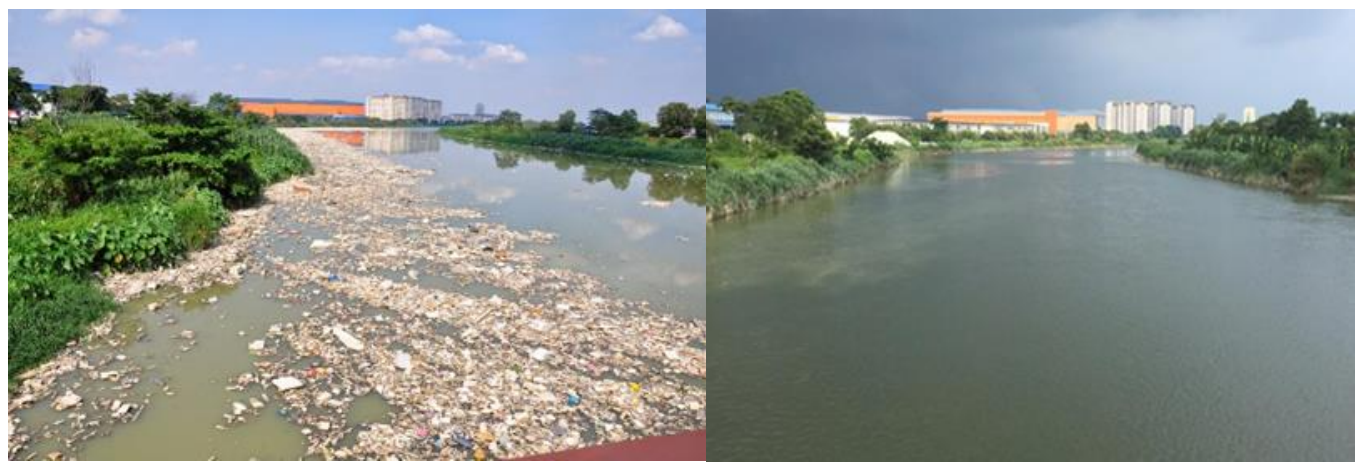

Fig 1: Klang River before and after the cleanup project

(Source: Majlis Perundingan SMG, 2020).

\subsection{Literature Review}

The river is a catalyst (Othman \& Majid, 2016) and promoting the sustainability of the residential area's existing socio-economic climate around it (Saad, Abdullah, \& Rosman, 2020a, 2020b). Now it has many issues social concerns on this river issue (Olsson \& Head, 2015). However, cross-sectoral collaborative governance in every state in Malaysia, including Selangor, seems to be considered weak in tackling river pollutants' issues. Although the level of disappointment fluctuates across topics and areas, researchers now highlight the fracture of administration across public and neighbourhood locales as a centre explanation behind sea administration's general disappointment (Dauvergne, 2018). There is little arrangement coordination across states, with global foundations working as meagre more than discourse gatherings (Dauvergne, 2018). Woldesenbet (2018) postulated that a low degree of cross-sectoral cooperation among different partners caused many water quality issues in Addis Ababa Rivers. Sunarharum, Sloan, and Susilawati (2021) emphasised that plenty of challenges in the coordinated effort with risk management. Somehow, Avoyan and Meijerink (2021) contended that the reconciliation and coordination of policies across sectors, just as a joint measure between strategy spaces, are of expanding significance for the two researchers and policymakers.

Another non-structural measure for the Klang River cleanup is a public outreach program. This people-centric initiative addresses the root causes of the issues and offers a long-term strategy. The teaching and promoting a sense of belonging and responsibility towards the river and environment paving the way to alleviate dependency on the costly structural measures. The Klang River cleanups' outreach program ludes advice from experts to make river assessment activities and evaluate pollution prevention systems. More recently, campaigns such as "Day Without Plastic" and "Love Our River" by the state have pushed for enactment to zero in on individual litter things in a high recurrence environment. Sakamoto, Shinozaki, and Shirakawa (2017) postulated that education activities do not necessarily improve the riverine climate. However, significant activities may add to increments in inspiration and nature of information on the individuals intrigued by ecological insurance.

\subsection{Methodology}

This study is a cross-sectional, quantitative study to measure the effectiveness of cross-sectoral collaborative governance and public outreach programs as river cleanup approaches for the Klang River. We chose a purposive sampling technique in the non-probability population of 82 respondents from the members of the river community and the staff of three (3) state agencies involved in river management, namely Lembaga Urus Air Selangor (LUAS), Department of Irrigation and Drainage (DID), and Majlis Perbandaran Klang (MPK). This sampling technique will enable the selection of limited groups based on their knowledge and expertise in the research subject and those who reside nearby. We collected data through a survey where the questionnaire was adapted from Xanthos et al. (2017), Woldesenbelt (2018), Dauvergne, 2018, Willis et al. (2017). It consists of 20 items. The first section collects demographic information of respondents using a nominal scale. The other three areas measure respondents' perception of river cleaning effectiveness, cross-sectoral collaboration, and public outreach program. A six-point Likert scale measured the items in these sections, 
starting from 1 (strongly disagree) to 6 (strongly agree). Respondents were asked to indicate an appropriate response. We developed a proposed structural equation model, as shown in Fig. 2.

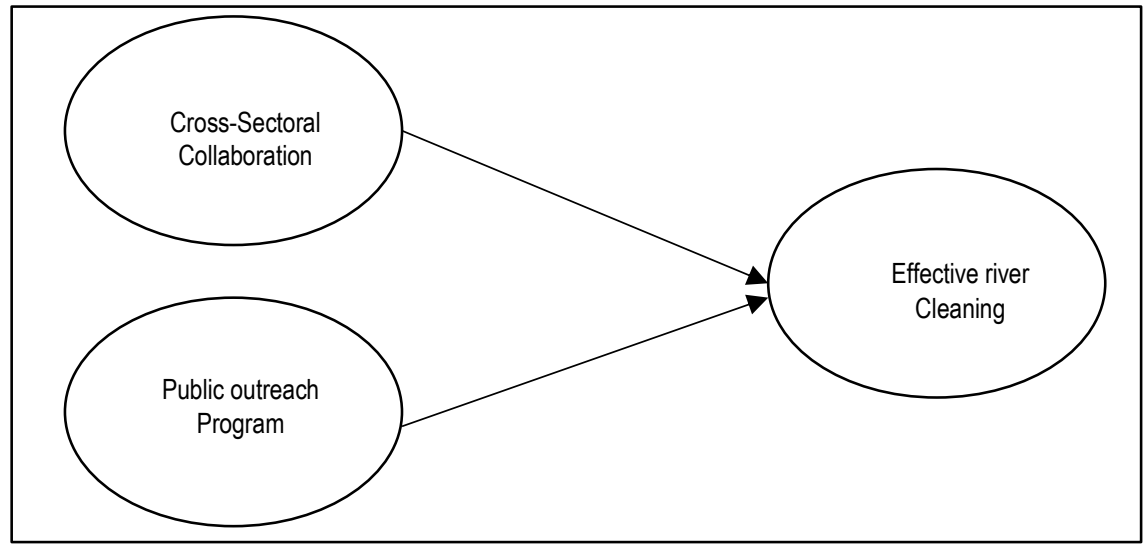

Fig. 2: Proposed framework for Effective River Cleaning

The items used to measure these constructs are described below.

Table 1. Items Description for Each Construct

\begin{tabular}{lll}
\hline Constructs & Measurement Item & Description \\
\hline Effective river & B1 & The cleaning program contributes to a cleaner river. \\
cleaning & B2 & The cleaning program reduces the amount of solid waste in the river. \\
& B3 & The cleaning program eliminates the odour/terrible smell of the river water. \\
& B4 & The cleaning program increases recreational activities along the river. \\
& B5 & The cleaning program brings back some wildlife species to the river. \\
\hline Cross-sectoral & C1 & Collaboration between agencies is necessary for the river cleaning program. \\
collaboration & C2 & Collaboration between public and private sectors increases the effectiveness of the river \\
& cleaning program. & \\
& C3 & Technical supports improve the river cleaning implementation. \\
& C4 & Water quality monitoring contributes to an effective river cleaning program. \\
& C5 & Closing down illegal dumping sites along the river contributes to a clean river. \\
\hline Public outreach & D1 & The program encourages river communities to take care of the river cleanliness. \\
program & D2 & The campaign 'Day Without Plastic' increases public awareness about river pollution caused \\
& by indiscriminate littering. & \\
& D3 & The campaign 'Love our River' increases public awareness about the importance of river \\
& cleanliness. & \\
& Engagement with school children increases the effectiveness of the river cleaning program.
\end{tabular}

Based on the proposed model, we formed hypotheses are as follows:

Hypothesis 1 (H1): There is a relationship between cross-sectoral collaboration and effective river cleaning.

Hypothesis $2(\mathrm{H} 2)$ : There is a relationship between public outreach programs and effective river cleaning.

We used SmartPLS software to test the hypotheses above and create the path model as in Figure 3. The significance of parameter estimates of PLS is assessed using the bootstrap method within the SmartPLS software. The estimated model is validated through the construct, convergent and discriminant validity values. Additionally, the $\mathrm{R}^{2}$ of the dependent variables will indicate the predictive path model's quality or ability. According to Hair et al. (2014), the $\mathrm{R}^{2}$ value of $0.25,050$ or 0.75 for dependent variables in structural models can be described as weak, moderate or substantial ability in prediction.

\subsection{Findings}

\subsection{Respondents' Profile}

Of the 82 respondents, $50 \%$ of them were male, while the other half were female. Various age groups represented survey respondents. Most respondents (45\%) were aged from 31 to 40 years old, while only $4 \%$ of respondents were aged above 50 years. $36 \%$ of the respondents were aged 18 to 30 years old, and the rest were from group age from 41 to 50 years. $68 \%$ of respondents indicated that their highest education level was obtained from the university. In comparison, $1 \%$ revealed that their education level is secondary school. The respondents from agency LUAS are $23 \%$, JPS is $16 \%$, MPK is $28 \%$, and $33 \%$ were from other agencies. $34 \%$ of these respondents have worked five years below, while $33 \%$ worked between 6 to 10 years, $17 \%$ worked 11 to 15 years, and $16 \%$ worked for more than 
15 years. The survey respondents also comprised 27\% Klang residents, $42 \%$ reside in Shah Alam, $7 \%$ from Petaling Jaya area, and $24 \%$ were from other areas. Table 2 gives a summary of the respondents' profile.

Table 2. Demographics of Respondents

\begin{tabular}{llcc}
\hline Measure & Items & Frequency & Percentage (\%) \\
\hline Gender & Male & 41 & 50 \\
Age (in years) & Female & 41 & 50 \\
& $18-30$ & 30 & 36 \\
& $31-40$ & 37 & 45 \\
Education Level & $41-50$ & 12 & 15 \\
& $>50$ & 3 & 4 \\
& University & 56 & 68 \\
Agency & College/Institute & 25 & 31 \\
& Secondary & 1 & 1 \\
& Primary & 0 & 0 \\
\multirow{5}{*}{ Working tenure (in years) } & LUAS & 19 & 23 \\
& JPS & 13 & 16 \\
& MPK & 23 & 28 \\
Residents & Others & 27 & 33 \\
& 6-10 & 28 & 34 \\
& $11-15$ & 27 & 33 \\
& $>15$ & 14 & 17 \\
& Klang & 13 & 16 \\
& Shah Alam & 22 & 27 \\
& Petaling Jaya & 34 & 42 \\
& Others & 6 & 7 \\
& & 20 & 24 \\
\hline
\end{tabular}

\subsection{Structural Model Assessment}

Validation of constructs is crucial in determining how well the measurement items' results fit the theories around which the model is developed. Hence, we assessed convergent and discriminant validity and internal consistency reliability. Table 3 shows all the values used in reassessing the measurement items and the constructs within the structural equation model of effective river cleaning. First, the respective loadings were examined if there are problems with any particular items. A cut-off value for loadings is at 0.7 , which indicates the items measuring a specific construct loaded highly on that construct, thus confirming construct validity. The third column in Table 3 depicts loadings for all items exceeding the benchmark value of 0.7 accepts item C5 for the CSC construct.

Next, we assessed the convergent validity to ensure that multiple items to measure the same concept agree. The loadings (>0.7), indicator reliability (>0.5), and average variance extracted (AVE) $(>0.5)$ were the indicators to assess convergent validity. Again, only item C5 has not fulfilled the recommended value for indicator reliability. However, the results show that AVE was in the range of 0.549 and 0.773 .

We used two measures to evaluate the internal consistency reliability of the measurement items. The Cronbach's Alpha values were above 0.6 , while the Composite Reliability values ranged from 0.857 to 0.932 . Both measures suggested that the measurement items are reliable. In this study, discriminant validity was evaluated by Heterotrait-monotrait (HTMT) criterion. The confidence interval (Cl) of HTMT, which can be obtained by the bootstrap method, does not contain the value of one, suggesting that discriminant validity has been established. Table 3 revealed that all construct measurements have adequate discriminant validities. Finally, the last column in Table 3 shows the t-values for each item larger than 2.58. These results indicate that all items are significant at 1 \& level of significance. Therefore, we decided to keep item $\mathrm{C} 5$ in the model.

Table 3. Items and Constructs Validation

\begin{tabular}{|c|c|c|c|c|c|c|c|c|}
\hline \multirow{2}{*}{$\begin{array}{l}\text { Model } \\
\text { Construct }\end{array}$} & \multirow{2}{*}{$\begin{array}{l}\text { Measurement } \\
\text { Items }\end{array}$} & \multicolumn{3}{|c|}{ Convergent Validity } & \multicolumn{2}{|c|}{ Internal Consistency Reliability } & \multirow{2}{*}{$\begin{array}{l}\begin{array}{l}\text { Discriminant } \\
\text { Validity }\end{array} \\
\text { HTMT Cl } \\
\text { does not } \\
\text { include } 1\end{array}$} & \multirow[b]{2}{*}{$\mathrm{t}$-values } \\
\hline & & Loadings & $\begin{array}{l}\text { Indicator } \\
\text { Reliability }\end{array}$ & AVE & $\begin{array}{l}\text { Cronbach's } \\
\text { Alpha }\end{array}$ & $\begin{array}{l}\text { Composite } \\
\text { Reliability }\end{array}$ & & \\
\hline \multirow{5}{*}{$\begin{array}{l}\text { Effective River } \\
\text { Cleaning (ERC) }\end{array}$} & B1 & 0.816 & 0.666 & 0.549 & 0.789 & 0.857 & Yes & $16.379^{* *}$ \\
\hline & B2 & 0.822 & 0.676 & & & & & $16.967^{* \star}$ \\
\hline & B3 & 0.723 & 0.523 & & & & & $9.545^{\star *}$ \\
\hline & B4 & 0.831 & 0.691 & & & & & $16.487^{* \star}$ \\
\hline & B5 & 0.834 & 0.696 & & & & & $19.008^{* *}$ \\
\hline \multirow{3}{*}{$\begin{array}{l}\text { Cross-sectoral } \\
\text { Collaboration } \\
\text { (CSC) }\end{array}$} & C1 & 0.825 & 0.681 & 0.650 & 0.867 & 0.902 & Yes & $19.635^{\star *}$ \\
\hline & $\mathrm{C} 2$ & 0.757 & 0.573 & & & & & $10.866^{\star \star}$ \\
\hline & C3 & 0.796 & 0.634 & & & & & $13.716^{* \star}$ \\
\hline
\end{tabular}




\begin{tabular}{|c|c|c|c|c|c|c|c|c|}
\hline & $\mathrm{C} 4$ & 0.739 & 0.546 & & & & & $10.55^{\star \star} 7$ \\
\hline & $\mathrm{C} 5$ & 0.560 & 0.314 & & & & & $4.695^{\star *}$ \\
\hline \multirow{4}{*}{$\begin{array}{l}\text { Public Outreach } \\
\text { Program (POP) }\end{array}$} & D1 & 0.867 & 0.752 & 0.773 & 0.902 & 0.932 & Yes & $19.574^{\star *}$ \\
\hline & $\mathrm{D} 2$ & 0.925 & 0.856 & & & & & $49.922^{\star *}$ \\
\hline & D3 & 0.864 & 0.746 & & & & & $19.912^{* *}$ \\
\hline & D4 & 0.860 & 0.740 & & & & & $23.773^{\star \star}$ \\
\hline
\end{tabular}

$\mathrm{t}$-values $>1.96^{*}(\mathrm{p}<0.05) ; \mathrm{t}-$ values $>2.58^{* *}(\mathrm{p}<0.01)$

\subsection{Structural Equation Model}

In the structural model, we estimated path coefficients using bootstrapping methods in PLS, as Chin (2010) conducted. The R2 value was used as a criterion for judging the quality of the structural model. The value describes the total variance explained by the dependent construct that measures the relationship of latent variables. The R2 values of $0.75,0.50$, and 0.25 in structural models represent the strong, medium, and weak determination coefficient (Hair et al., 2014). Figure 3 demonstrates the path model between cross-sectoral collaboration, public outreach program and effectiveness of river cleaning. The resulting R2 values of 0.378 suggest that $37.8 \%$ of the total variation in effective river cleaning can be explained by the other two constructs and can be considered a moderate determination coefficient.

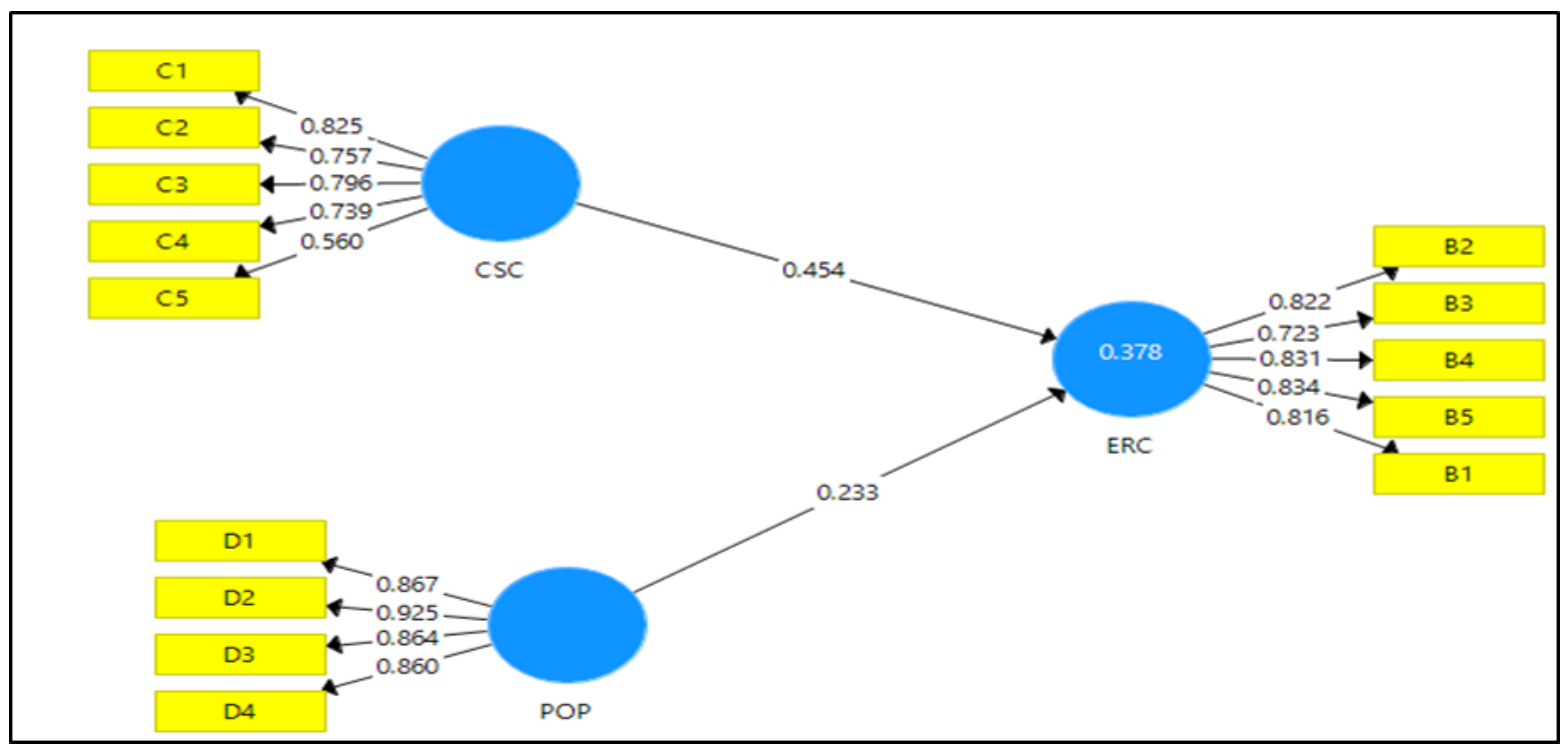

Fig 3. Partial Least Squares Path Model of Perception on Effectiveness River Cleaning9AN

Table 4 denotes the results for the path coefficient for each hypothesis. The results indicate that $t$-values for both hypotheses are larger than 1.96. Therefore, our proposed relationships between cross-sectoral collaboration and perception on the effectiveness of river cleaning ( $\mathrm{H} 1)$ and public outreach program and perception on the effectiveness of river are significant at a $5 \%$ level $(t>1.96)$.

Table 4. Path Coefficient and Hypothesis Testing9AN

\begin{tabular}{llllll}
\hline Hypothesis & Relationship & $\beta$ Coefficient & SE & t-values & Supported \\
\hline H1 & CSC $\rightarrow$ ERC & 0.454 & 0.102 & 4.432 & Yes \\
H2 & POP $\rightarrow$ ERC & 0.232 & 0.108 & 2.163 & Yes \\
\hline \multicolumn{5}{c}{ t-values $>1.96^{*}(p<0.05) ;$ t-values $>2.58^{* *}(p<0.01)$} \\
\hline
\end{tabular}

\subsection{Discussion}

Significantly, this research is intended to identify and understand the sufficient river cleaning approaches using non-structural measures of cross-sectoral collaborative governance and public outreach programs. It is undertaken by the state to improve the water and environmental quality to benefit humans, wildlife, and nature. The partnership between the government and private sectors: SMG, LUAS, river community and DID increases the effectiveness of the river cleaning program. This idea is similar to Willis et al. (2017) study that public outreach program that provides a more sustainable approach towards effective river cleaning needs. The education on Programs such as "Day Without Plastic" and "Love Our River" the Public Outreach Program is the right initiative to educate people on the importance of river cleanliness as supported by Sakamoto et al. (2017). The technical supports also improve river cleaning. It is necessary to have the right people and the correct agenda to have water quality monitoring and closing down illegal dumping sites along the river. The amount of waste has been reduced and there is expanded mindfulness as the corporate areas, NGOs, and the public. The punishment ought to be made more serious, including a compulsory jail term or, in any event, caning to be proportionate with the 
offences' reality. If a factory is responsible for extreme emissions, the legislation must grant regulators the authority to shut it down or put it out of business. The project of river cleaning has directly impacted the river water quality. Though the present study only involved respondents from agencies whom expertise in river basin management and those who reside within the study area, the generalisation of the finding of this study could be improved if the sample came from the upstream and downstream along the Klang River as well as rivers across the country.

\subsection{Conclusion \& Recommendations}

By recognising the Cross-sectoral Collaboration and Public Outreach Program as means for Effective River Cleaning, practitioners and related government agencies may find a long-term solution for river and river basin management concerning reducing litter and water quality improvement. Other than awareness programs and laws and regulations aimed at a later stage of life, education seems to be more effective in nurturing younger generations to be environmentally conscious citizens. The Public Outreach Program is also one of the non-structural measures found to have increased river cleaning effectiveness. Ideally, there will be more coordinated efforts between government areas and NGOs to make a cleaner stream in the future. This initiative aligns with the government's Sustainable Development Goal 17: Strengthening implementation mechanisms and revitalising global partnerships for sustainable development. The outcomes show that successful waterway cleaning exercises, for example, counteraction and expulsion of litter from the Klang River, have tremendous beneficial effects on water quality, climate, biological frameworks, widely varied vegetation, and aquatic life and territory. The sustainability of water resource is improved, influencing plants and living organic entities, the populace's wellbeing, and the economy. More such programs are encouraged to all related stakeholders. Providing litter education programs has significantly reduced floatable waste and raised the quality of life and public awareness. It forms a sense of environmental responsibility in every individual and the quality of life of the environment. Future research on the next level of water management - river beautification and rejuvenation should be considered.

\section{Acknowledgements}

We would like to acknowledge everyone who played a role in our accomplishments especially respondents from Lembaga Urus Air Selangor (LUAS), Department of Irrigation and Drainage (DID), Klang Local Council (MPK), Shah Alam Local Council (MBSA) and Klang river community, each of whom has provided patient advice and guidance throughout the research process. Thank you all for your unwavering support.

\section{Paper Contribution to Related Field of Study}

This paper would add to the literature of sustainable environment specifically in the field of river management and conservation, public outreach programs, as well as collaboration of non-structural measures.

\section{References}

Avoyan, E., \& Meijerink, S. (2021). Cross-sector collaboration within Dutch flood risk governance: historical analysis of external triggers. International Journal of Water Resources Development, 37(1), 24-47.

Dauvergne, P. (2018). Why is global governance of plastic failing the oceans? Global Environmental Change 51 (2018) 22-31.

Hair, J. F., Hult, G. T. M., Ringle, C. M. and Sarstedt, M. (2014), A Primer on Partial Least Squares Structural Equation Modeling (PLS-SEM), Sage, Thousand Oaks, CA.

Li, Z., Zhang, X., Jiang, R., \& Huang, X. (2020, February). Establishing Multi-support River Chief System (RCS) to Achieve Long-term Restoration and Management Effectiveness of Transboundary Rivers. In IOP Conference Series: Earth and Environmental Science (Vol. 455, No. 1, p. 012191). IOP Publishing.

Majlis Perundingan Selangor Maritime Gateway, Muzaffar Hotel, Melaka, 20 February, 2020.

Malaysiakini Advertorial (2014): Breathing New Life into Kuala Lumpur's Rivers. Published on 11 Aug 2014.

Muhammad, A. A., Nur, H. H., Ismail, Y., Mohammadreza, G. (2017). Study of the Impacts of Some Domestic Pollutants on the Freshwater Fish Community in the Klang River, Malaysia.

Olsson, L., Head, B. (2015). Urban water governance in times of multiple stressors: an editorial. Ecol Soc 20(1):27. https://doi.org/10.5751/ES-07300-200127.

Othman, A. R., \& Abdul Majid, N. H. (2016). Urban River and Its Heritage Value: A river of life at Precinct 7, Kuala Lumpur. Environment-Behaviour Proceedings Journal, 1(1), 58-67.

Saad, M., Abdullah, N.N., \& Rosman, S.N.H. (2020a). Developing the Rural Town of Panchor into a Future River-based Tourism Destination: Host Community Perception. Environment-Behaviour Proceedings Journal, 5 (14 (2020)). pp. 155-161. 
Saad, M., Abdullah, N.N., \& Rosman, S.N.H. (2020b). Exploring host community perception of Panchor town for tourist destination based on social exchange theory. Asian Journal of Behavioural Studies, 5 (19). pp. 1-10. E-ISSN 2398-4295

Sakamoto, T., Shinozaki, Y., and Shirakawa, N. (2017): Nationwide investigation of citizen-based river groups in Japan: their potential for sustainable river management, International Journal of River Basin Management.

Siraj, M. Z., Mohd Hanafis, A. H., \& Nor 'Asyikin, M. H. (2016). 80 tonnes a day: https:// www. hmetro.com.my / mutakhir / 2016 / 10 / 172583 / 80-tan-metrik-sehari. October 9, 2016

Sunarharum, T. M., Sloan, M., \& Susilawati, C. (2021). Collaborative Approach for Community Resilience to Natural Disaster: Perspectives on Flood Risk Management in Jakarta, Indonesia. In Sustainability in Energy and Buildings 2020 (pp. 275-284). Springer, Singapore.

Willis, K., Maureaud, C., Wilcox, C., \& Hardesty, B. D. (2018). How successful are waste abatement campaigns and government policies at reducing plastic waste into the marine environment? Marine Policy, 96, 243-249.

Woldesenbet, W.G. (2018). Collaborative governance: assessing the problem of weak cross-sectoral collaborations for the governance of Addis Ababa Rivers. Applied Water Science (2018) 8:116.

Wu, C., Ju, M., Wang, L., Gu, X., \& Jiang, C. (2020). Public Participation of the River Chief System in China: Current Trends, Problems, and Perspectives. Water, 12(12), 3496.

Xanthos, D., Walker, T.R. International policies to reduce plastic marine pollution from single-use plastics (plastic bags and microbeads): a review, Mar. Pollut. Bull. (2017). 